\title{
Integration of Different Individual Heating Scenarios and Energy Storages into Hybrid Energy System Model of China for 2030
}

\author{
Muhammad Faizan Tahir ${ }^{1}$, Haoyong Chen ${ }^{1, *}$, Muhammad Sufyan Javed ${ }^{2,3}{ }^{(0)}$, Irfan Jameel ${ }^{4}(\mathbb{D}$, \\ Asad Khan ${ }^{5}$ and Saifullah Adnan ${ }^{6}$ (D) \\ 1 School of Electric Power, South China University of Technology, Guangzhou 510640, China; \\ epfaizantahir_2k7@mail.scut.edu.cn \\ 2 Department of Physics, Jinan University, Guangzhou 510640, China; sufyanjaved@jnu.edu.cn \\ 3 Department of Physics, COMSATS University Islamabad, Lahore Campus, Punjab 54000, Pakistan \\ College of Energy and Electrical Engineering, Hohai University, Nanjing 210098, China; i.jamil@hhu.edu.cn \\ 5 School of Computer Science, South China Normal University, Guangzhou 510640, China; \\ asad@mail.ustc.edu.cn \\ 6 School of Electronics and Information Engineering, South University of Technology, \\ Guangzhou 510640, China; eesaifullahadnan@mail.scut.edu.cn \\ * Correspondence: eehychen@scut.edu.cn; Tel.: +86-020-29040352
}

Received: 30 April 2019; Accepted: 28 May 2019; Published: 31 May 2019

check for updates

\begin{abstract}
Traditional energy supply infrastructures are on the brink of facing a major transformation due to energy security concerns, environment pollution, renewable energy intermittency and fossil fuel scarcity. A hybrid energy system constitutes the integration of different energy carriers like electricity, heat and fuel which play a vital role in addressing the above challenges. Various technological options like combined heat and power, heat pumps, electrolysers and energy storages ease out multiple carrier integration in an energy hub to increase system flexibility and efficiency. This work models the hybrid energy system of China for the year 2030 by using EnergyPLAN. Atmosphere decarbonization is achieved by replacing conventional coal and natural gas boilers with alternative individual heating sources like hydrogen operated micro combined heat and power natural gas micro combined heat and power and heat pumps. Moreover, rockbed storage as well as single and double penstock pumped hydro storages are added in the proposed system in order to cope with the stochastic nature of intermittent renewable energy such as wind and solar photovoltaic. The technical simulation strategy is employed to analyze the optimal combination of energy producing components by determining annual costs, fuel consumption and $\mathrm{CO}_{2}$ emissions. The results substantiate that a heat pump and double penstock pumped hydro storage addition to the individual heating and electricity network not only proves to be an economically viable option but also reduces fuel consumption and emissions.
\end{abstract}

Keywords: energy hub; EnergyPLAN; hybrid energy system; individual heating; intermittent renewable energy; pumped hydro storages; rockbed storage

\section{Introduction}

The global energy demand is continuously rising due to an increase in population and economic development [1]. Although enough energy sources (like hydro, wind, solar, geothermal) are available in the world to meet the constantly increasing demand, the depletion of fossil fuels and stochastic nature of intermittent renewable energy (IRE) sources pose challenges to the future acquisition of a sustainable system. Therefore, a hybrid energy system (HES) which involves the integration of multiple energy carriers (like electricity and heat) is becoming increasingly significant because it can 
counter-balance the drawbacks of these carriers [2,3]. Electricity and district heating contribute to the highest share of world's energy demand, which is mostly used in household activities, industrial works and other purposes. Specifically, heat is the largest consumed energy carrier and $46 \%$ of heat is utilized in the residential sector, e.g., space and water heating. Heating in the residential sector in the UK accounts for $11 \%$ of greenhouse gas (GHG) emissions in the UK [4]. It is estimated that individual heating in dwellings produces around 19\% of global emissions [5]. Consequently, other than electricity and district heating, individual heating is gaining attention in the context of a HES in order to protect the environment.

China is the world's largest energy consumer and $\mathrm{CO}_{2}$ emitter. The country has the second largest district heating grid and is shifting its focus towards a HES as well [6,7]. The Chinese government initiated the 'Internet+smart energy' project in 2015 that facilitates the integration of electricity, thermal energy and natural gas (Ngas) [8]. Several pilot projects have already been completed in Jiaxing city (Zhejiang province), Qilian city (Qinghai province) and Shanghai (municipality). China's residential energy demand has rapidly increased over the past two decades due to industrialization and an increase in income levels [9]. Especially in the northern cities of China like Harbin, individual heating accounts for more than $30 \%$ of total heating demand in the residential sector [10].

A hybrid energy system also plays a key role in increasing system efficiency and decreasing GHG emissions by reducing the dependency on widely used fossil fuel sources and easing out IRE integration [11]. Technologies like the combined heat and power (CHP), energy storage (ES), electrolyser and heat pumps facilitate the integration of different energy carriers. These technologies not only increase the flexibility of the overall energy system but also help in balancing the fluctuations of IRE sources such as wind and solar photovoltaic (PV). The energy hub approach proposed by [12] has become successful for the integration of HES. Moreover, energy storage has been extensively used to improve system resilience by mitigating the uncertainties and variability of IRE. Many storage technologies in HES have been used to cope with the stochastic nature of IRE and pumped hydro storage (PHS) is the most mature and well-established technology [13]. Thermal storage like rockbed storage is becoming a viable choice to integrate IRE due to its fast transfer rate, higher thermal conductivity and low initial costs [14].

Shafiqur R. et al. [15] elaborated the technological review of PHS while Bjarne S. [16] illustrates the development of PHS in Germany. The feasibility analysis of PHS for integrating renewable energy is proposed by [17]. Rockbed heat transfer analysis is discussed in [18] while the comprehensive review of such thermal storages and its role in integrating IRE is analyzed in [19]. Individual and district heating comparisons are undertaken in [20]. A new strategy for the European Union for Individual heat pumps and district heating is proposed by Connolly et al. [21]. The role of micro-CHP (M-CHP) in increasing the utilization of available energy is proposed in [22] while the role of an electrolyser in a HES for greenhouse heating is presented in [23].

However, comprehensive individual heating planning by evaluating heat pumps, micro CHP and electrolyzers on a massive scale of the yearly hybrid energy system model are mostly neglected, especially in Asia. Thus far, around $90 \%$ of heat is produced by coal and Ngas boilers which are the main source of carbon emissions. Therefore, in order to fill the gap, this research aims to be the first study to investigate alternative individual heating scenarios of China in a HES to replace predominant fossil fuel boilers. Moreover, most of the PHS analysis studies for integrating IRE are limited to single penstock PHS that does not allow charging and discharging simultaneously. However, the simultaneous operation of turbine and pump is possible with double penstock which improves the performance of storage and allows more penetration of IRE.

This work conducts the technical analysis of both single and double penstock PHS using EnergyPLAN tool. Besides PHS, rockbed storage is also exploited to find the most economical and fossil-free alternative for integrating maximum renewable energy in HES. In this paper, electricity and heat energy data are collected to model HES of China for the year 2030 by using the smart energy hub approach in EnergyPLAN. A technical analysis of M-CHP, electrolysers and heat pumps in individual 
heating infrastructure is carried out to replace coal and Ngas boilers, which would help in achieving cleaner and cost-effective solutions. Simulation strategy 1 (balancing heat demand) is employed to find out prominent factors like annual costs, primary energy supply (PES) or fuel consumption and $\mathrm{CO}_{2}$ emissions. Moreover, energy storages such as rockbed storage, single and double penstock PHS are introduced in a HES to integrate the maximum amount of IRE by using simulation strategy 1 (balancing heat demand) and 2 (balancing both heat and electricity demand). These storage additions help in decarbonizing the atmosphere by reducing the dependency on fossil fuel sources. Besides the aforementioned factors (annual costs, $\mathrm{PES}, \mathrm{CO}_{2}$ emissions) renewable energy share, critical excess and exportable excess are also determined for every storage.

The rest of the paper is organized as follows. Section 2 elaborates methodology while Section 3 describes data simulation required for HES modelling of China by 2030. Sections 4 and 5 demonstrate different cases for individual heating and energy storages modelling. Section 6 represents the results of the simulation and Section 7 concludes the paper.

\section{Methodology}

The HES of China by the year 2030, that includes the electricity network, district heating network and individual heating network, has been analyzed using the EnergyPLAN software. EnergyPLAN was developed in 1999 by Henrik Lund and uses hourly steps to model regional or national energy systems; to date, 14 versions have been released [24]. The deterministic nature of this tool always results in the same outputs against the same inputs. General inputs for this freeware energy analysis tool are demands (electricity, heating, cooling and so on), production component capacities (fossil fuels plants, renewable energy sources and so on), conversion unit capacities (electrolysers, CHP and so on), costs (investment costs, lifetime and percentage of investment) and different simulation strategies (technical simulation and market economic simulation). Annual production, energy balance, fuel consumption, emissions and import/export are the outputs of this model. The combination of object-oriented programming and integrated development environment known as Delphi Pascal programming is used to calculate the above outputs. EnergyPLAN is already a developed tool that has been used in modelling $100 \%$ renewable energy in countries like Ireland, Denmark, Croatia, Latvia, Netherland, Portugal, Macedonia and Finland [25-32]. This energy system analysis tool has already been used in Hong Kong energy modelling and several case studies of China including, Chongming, Beijing and Jiangsu province [33-36]. Further, EnergyPLAN has also exploited the role of district heating [37-40], CHP [41-43] and vehicle to grid [44-47] in sustainable energy supply.

The utilization of various components, conversions from one form to another and the coordination of smart grids within the EnergyPLAN model makes this system a smart energy system that achieves higher efficiency with reduced costs and emissions. The proposed smart energy hub including inputs, outputs, converters and storages is illustrated in Figure 1.

The above smart energy hub modelling of the electricity network, district heating network and energy constraints have already been proposed in our previous article [48]. However, this work analyzes different cases of the individual heating scenario indicated with dashed lines in Figure 1. Further, various energy storages like pumped hydro storage with single penstock, pumped hydro storage with double penstock and rock bed storages are also investigated to integrate the maximum share of renewable energy while making the system cost-effective as well. The technical simulation strategy is employed to find out the optimal combination of different storages. The operation of each component in the hub is defined to determine the least consuming option. Two different simulation strategies that are discussed below determines the following prominent factors like annual costs, fuel consumption, total emissions, renewable energy share, critical and exportable excess electricity.

(1) Technical simulation strategy 1

In this strategy, all units produce energy according to heat demands and condensing unit CHP do not operate according to variations of renewable energy sources. In this strategy, the units are given 
priority according to the following sequence: industrial CHP (CSHP), CHP units, heat pumps and peak load boilers.

(2) Technical simulation strategy 2

In this strategy, all units including CHP produce energy according to electricity and heat demands. The export of electricity is minimized using heat pumps at CHP plants which will increase electricity consumption and decrease the electricity production. Therefore, CHP units have to decrease heat production in order to fulfill the electricity demand.

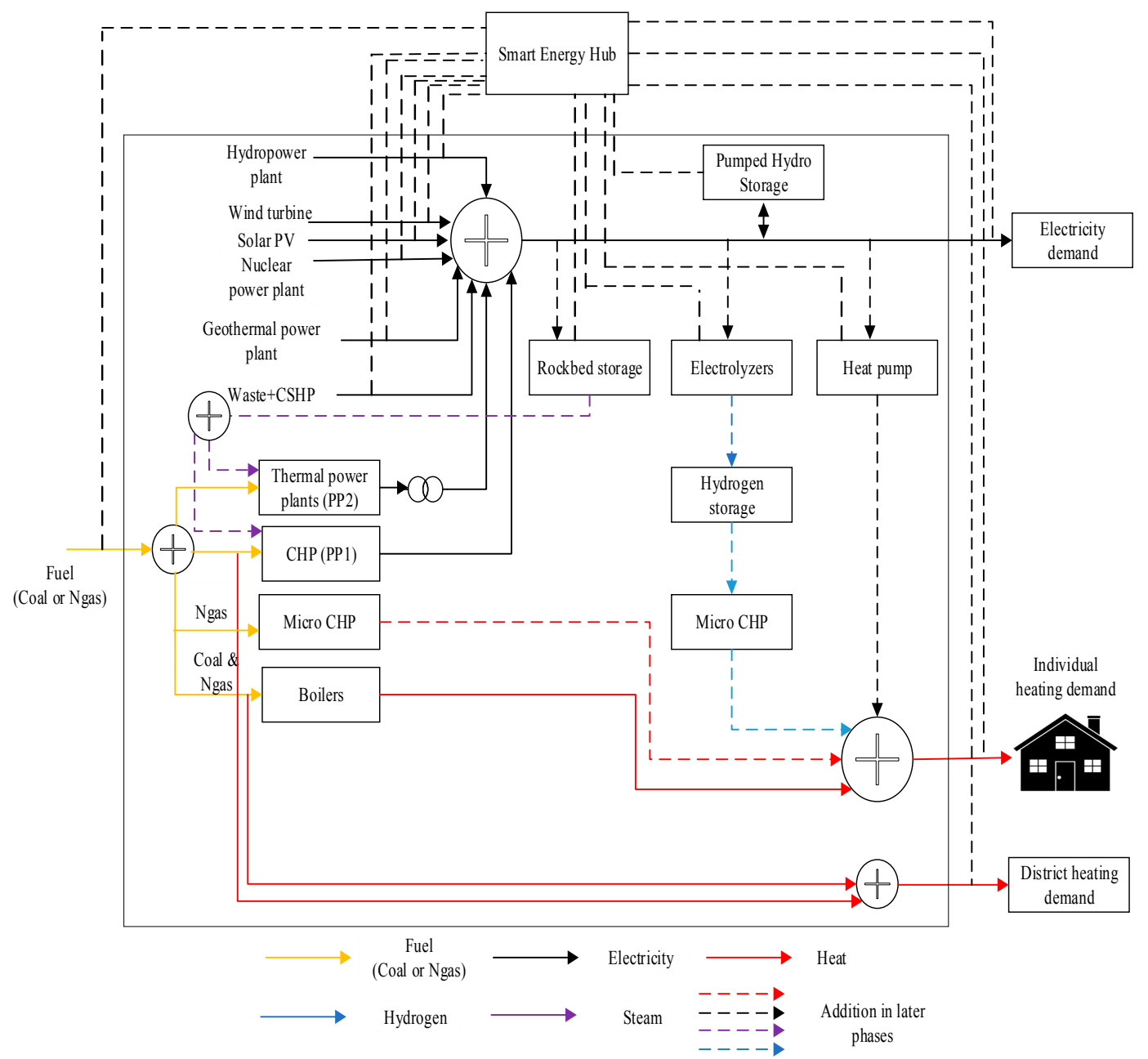

Figure 1. Hybrid energy system modelling using smart energy hub approach for year 2030.

In the aforementioned strategies, the proposed model also takes into account the following constraints:

(i) Conventionally, the system stability is maintained by large CHP and thermal power plants, unless one specifies that little percentage of renewable energy can also provide stabilization but only after eliminating the uncertainties associated with these sources by the help of energy storages. Therefore, during any hour the specified share of thermal power plants and CHP to keep the system stable falls below the prescribed percentage, EnergyPLAN shows the warning 'grid stab. problem' and if this warning is not addressed the system may lead to cascaded failure [49,50].

(ii) EnergyPLAN shows the 'PP/import' warning if during any hour there is not enough capacity to fulfill electricity demand. 
(iii) It always makes sure during the modelling that the generated electricity does not increase beyond the transmission line capacity and this surplus electricity is represented by critical excess electricity production in EnegyPLAN.

\section{Data for the Simulation Hybrid Energy System of China for 2030}

The composite HES analysis is investigated in hourly steps resolution for the year 2030 by using the latest version (14) of EnergyPLAN [24]. A lot of assumptions have been made by different researchers and organizations in order to predict future energy demands [51,52]. Nevertheless, the electricity demand for the year 2030 is estimated by taking a 1.5\% annual increase rate, as this rate was suggested by the International Energy Agency from 2014-2030 for China's national energy demand [53]. Further, many state-owned websites [54,55], the China energy yearbook [56], State Grid Corporation of China and China power industry statistics [57] are used to collect initial data.

Based on [53-57], electricity demand including losses and electric heating for the year 2030 is estimated to be 11,047 and $153 \mathrm{TWh} /$ year respectively. Therefore, the total electricity demand of 11,200 TWh/year is fulfilled by renewable energy sources like wind and PV, geothermal, hydropower, CHP (which is represented by PP1 in EnergyPLAN), CSHP and thermal power plants (which is represented by PP2 in EnergyPLAN). Figures 2 and 3 demonstrate the monthly electricity consumption for the specified year (2030) and production by the aforementioned sources.

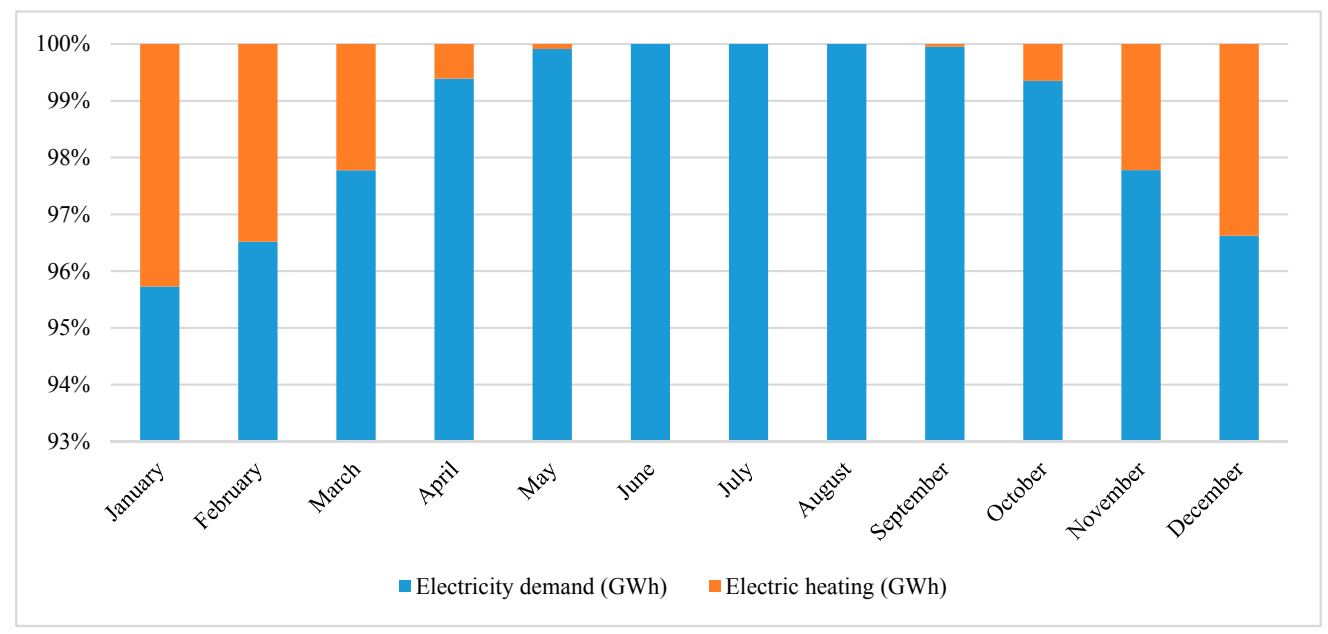

Figure 2. Electricity demand including electric heating for year 2030.

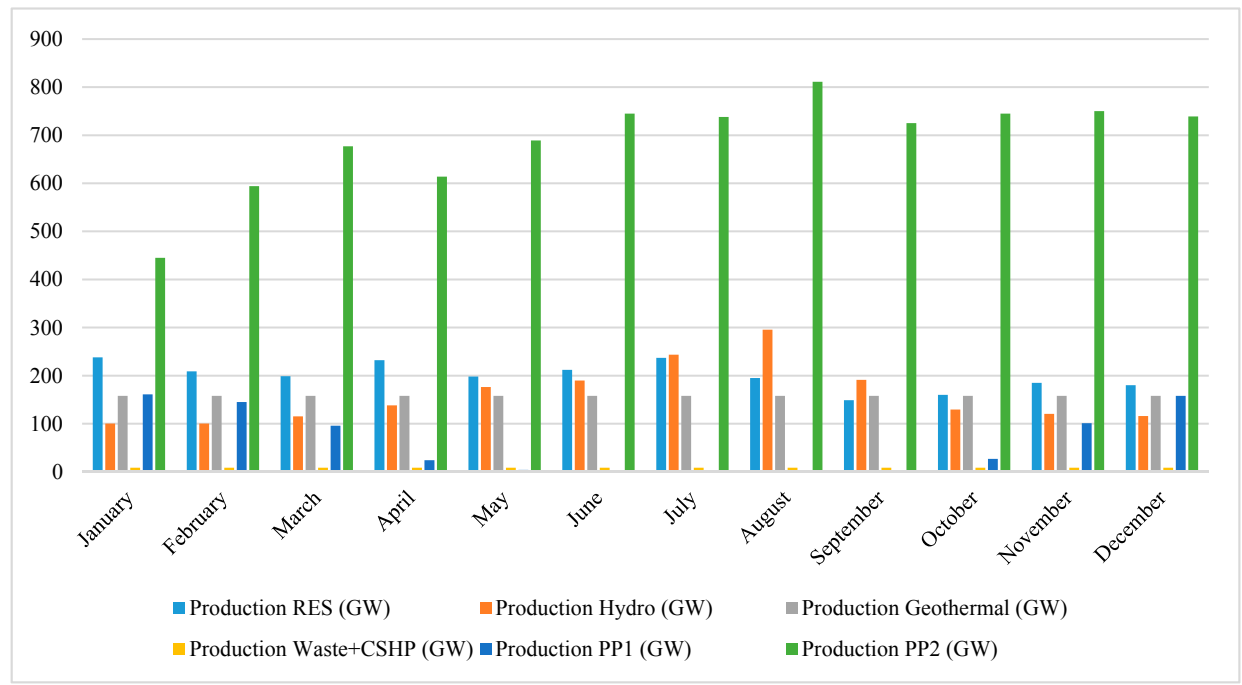

Figure 3. Electricity production by component wise for year 2030. 
District heating demand for 2030 which is met by boilers and CHP found out to be $1216 \mathrm{TWh} /$ year $[52,53,56,57]$. Besides the district heating demand, individual heating also contributes to a considerable proportion of the total heating demand. The individual heating demand which is met by Ngas and coal boilers is $390 \mathrm{TWh} /$ year that makes the total heating demand $1607 \mathrm{TWh} /$ year. The monthly distribution of district and individual heating consumption and production by $\mathrm{CHP}$ and boilers are shown in Figure 4.

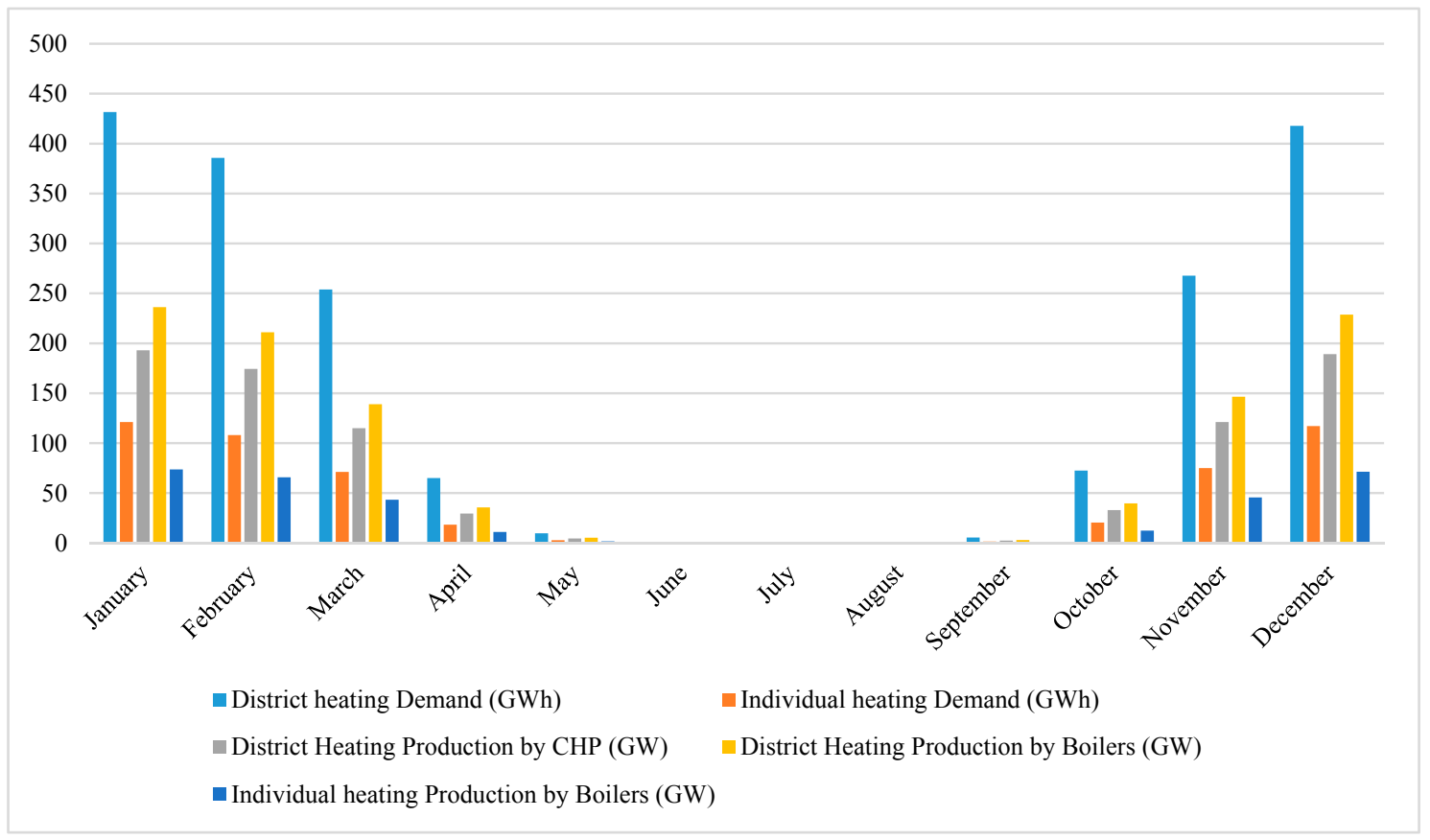

Figure 4. District and individual heating consumption and production by $\mathrm{CHP}$ and boilers.

Demand per building, which is used to calculate the number of households with individual heating, is assumed as 15,000 kWh/year and total Individual heating (390 TWh/year) also includes electric heating (153 TWh/year). The heat demand in individual houses is met by the following heat producing technologies:

1. Boilers than can be fired by Coal, oil and Ngas.

2. Micro CHP is fired by hydrogen or Ngas.

3. Heat pumps use electricity to generate heat.

District heating modelling and the analysis of alternate scenarios for reducing $\mathrm{CO}_{2}$ emissions by taking into account cost analysis were addressed in our previous article [48]. However, this work focuses on finding the optimal scenarios for individual heating infrastructure and observing the roles of different storages on the electricity network for integrating maximum renewable energy. All of the aforementioned heat producing components (1,2 and 3) were analyzed by employing the technical simulation strategy 1 of EnergyPLAN.

The individual heating for 2030 using coal and Ngas boilers to meet heat demand is considered as the base case and the inputs of these boilers are shown in Table 1.

Table 1. Base Case (Coal and Ngas Boilers) Components Specifications.

\begin{tabular}{cccc}
\hline Technology & Fuel Input (MWh) & Thermal Efficiency & Heat Demand (TWh/year) \\
\hline Coal boiler & 373 & 0.35 & 130.55 \\
Ngas Boiler & 122 & 0.88 & 107.36 \\
\hline
\end{tabular}


Other than specifying demands, EnergyPLAN also requires a costs analysis of all the production components in order to perform technical simulation. These costs analyses include total investment costs, a lifetime of the respective production unit and the percentage of investment, which are shown in Figures 5 and 6.

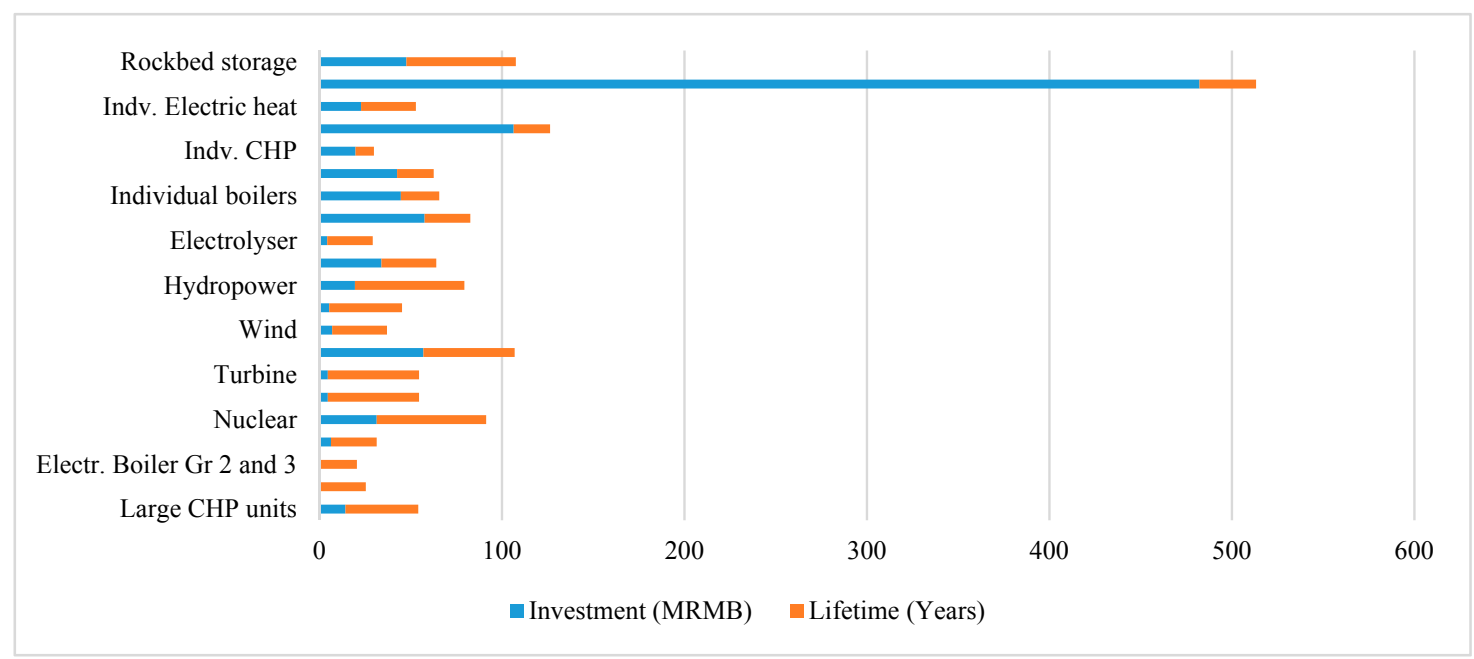

Figure 5. Production unit investment costs and lifetime.

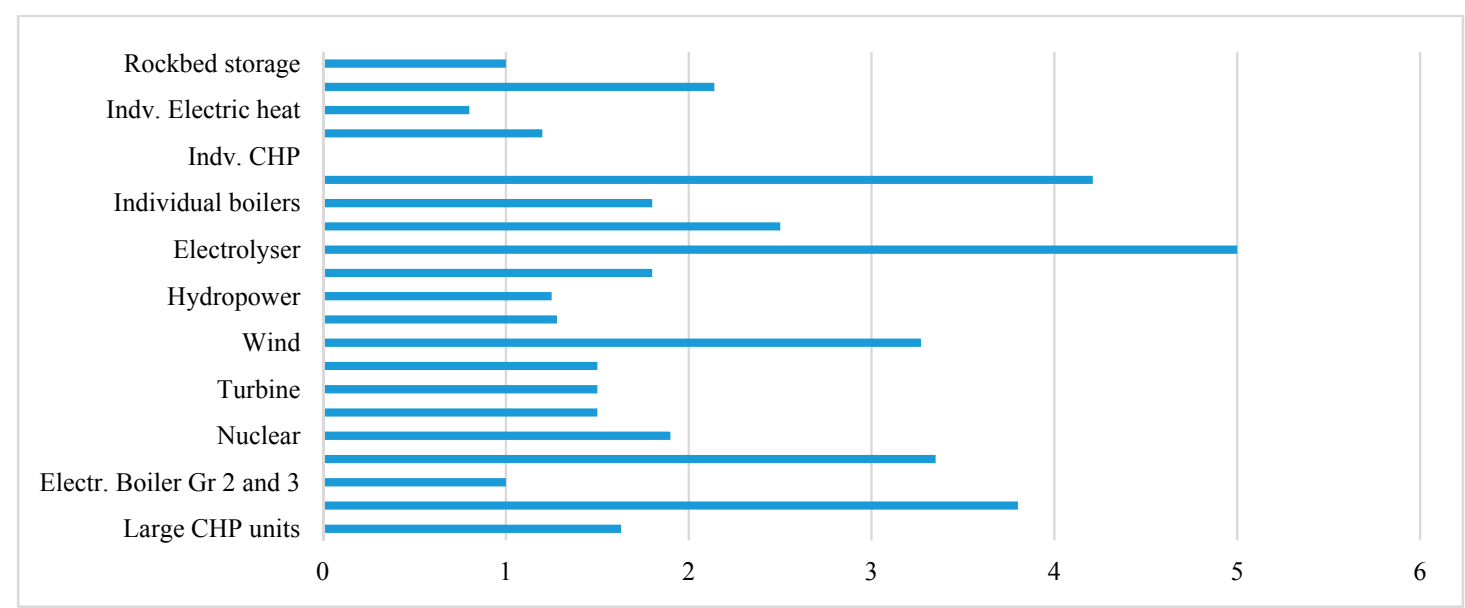

Figure 6. Production unit percentage of investment costs.

\section{Modelling of Different Cases of Individual Heating}

\subsection{Individual Heating Base Case}

Individual heating for the base case is met by boilers-only which are fired by coal and Ngas as shown in Figure 7. Heat demands can be computed by multiplying fuel input $(F)$ to respective boiler efficiency $\left(\eta_{h}^{B}\right)$ as represented in Equations (1) and (2).

$$
\begin{gathered}
P_{I H}=F \times \eta_{h}^{B} \\
P_{I H}=\left(F^{\text {coal }} \times \eta_{h}^{\text {coal }}\right)+\left(F^{N g a s} \times \eta_{h}^{N g a s}\right)
\end{gathered}
$$

In this work, subscripts represent energy type while superscripts illustrate the energy-producing component. Similarly in the above equations subscripts, $I H$ and $h$ represents total individual heating and heat produced by respective component while superscript $B$ depicts boiler. Further, superscripts like coal and Ngas represent the boilers firing source, which are coal and Ngas. 


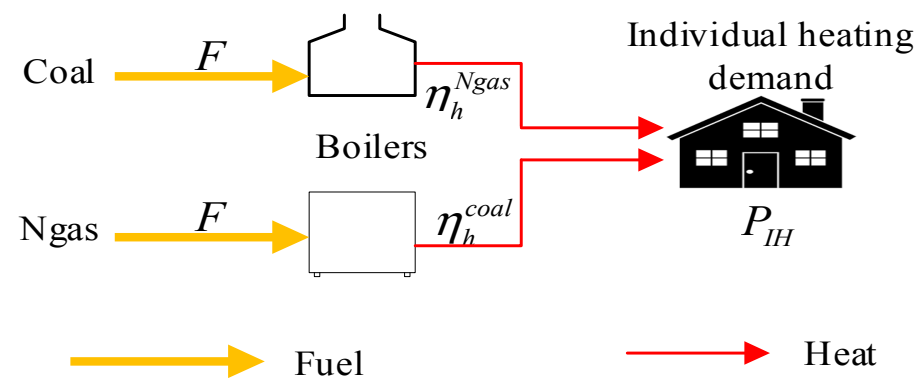

Figure 7. Coal and Ngas boilers are used to meet base case individual heating demand.

In this work, the individual heating demand other than coal and Ngas boilers are met by adding Ngas M-CHP, H2 M-CHP and heat pump. The individual heating infrastructure is divided into three cases that are summarized in Table 2.

Table 2. Summary of Different Cases of Individual Heating Infrastructure.

\begin{tabular}{|c|c|c|c|c|c|}
\hline \multirow{2}{*}{ Cases } & \multicolumn{5}{|c|}{ Technology } \\
\hline & Coal Boilers & Ngas Boilers & Ngas Micro CHP & H2 Micro CHP & Heat Pump \\
\hline Base case: only boilers & $\sqrt{ }$ & $\sqrt{ }$ & $x$ & $x$ & $x$ \\
\hline Case 1 & $\sqrt{ }$ & $\sqrt{ }$ & $\sqrt{ }$ & $\times$ & $x$ \\
\hline Case 2 & $\sqrt{ }$ & $\sqrt{ }$ & $x$ & $\sqrt{ }$ & $x$ \\
\hline Case 3 & $\sqrt{ }$ & $\sqrt{ }$ & $x$ & $x$ & $\sqrt{ }$ \\
\hline
\end{tabular}

To find the optimal combination of individual heating components, the above cases are further divided into three subcases:

Subcase 1: Coal boilers are replaced with $\mathrm{H} 2 \mathrm{M}-\mathrm{CHP} / \mathrm{Ngas}$ micro CHP/Heat pump.

Subcase 2: Ngas boilers are replaced with H2 M-CHP/Ngas M-CHP/Heat pump.

Subcase 3: Both coal and Ngas boilers are replaced with H2 M-CHP/Ngas M-CHP/Heat pump.

\subsection{Case 1: $\mathrm{H}_{2}$ Micro $\mathrm{CHP}$}

Efficient Micro CHP is the potential driving force to substitute less efficient fossil fuel boilers. In this case, M-CHP is operated by hydrogen is appended in HES along with base case boilers as shown in Figure 8. Individual heating demands for all subcases are shown in Equations (3)-(5).

Subcase 1:

$$
P_{I H}=\left(F^{N g a s} \times \eta_{h}^{N g a s}\right)+\left(F_{H_{2}}^{E l c} \times \eta_{h}^{M-C H P}\right)
$$

Subcase 2:

$$
P_{I H}=\left(F^{\text {coal }} \times \eta_{h}^{\text {coal }}\right)+\left(F_{H_{2}}^{E l c} \times \eta_{h}^{M-C H P}\right)
$$

Subcase 3:

$$
P_{I H}=F_{H_{2}}^{E l c} \times \eta_{h}^{M-C H P}
$$

where, subscript $H_{2}$ represents hydrogen produced by electrolysers while $M-C H P$ and Elc indicate energy-producing components micro $\mathrm{CHP}$ and electrolysers.

\section{Electrolysers for Micro CHP}

After specifying the heat demand for a hydrogen-based M-CHP system, the minimum capacity of electrolyser is determined to supply the necessary hydrogen. This electrolyser capacity, along with hydrogen storage content, if any, is used as input in the liquid and gas fuel tab within the supply section. Hydrogen production by electrolysers $\left(F_{\mathrm{H}_{2}}^{E l c}\right)$ is considered as the average hydrogen consumption of the 
M-CHP system $\left(F_{H_{2}}^{M-C H P-A v g}\right)$ in order to determine the minimum capacity of electrolysers $\left(C_{M i n}^{E l c}\right)$ as shown in Equation (6).

$$
F_{H_{2}}^{E l c}=F_{H_{2}}^{M-C H P-A v g}=\frac{F_{H_{2}}^{M-C H P}}{8784}
$$

Hydrogen storage content $\left(S_{\mathrm{H}_{2}}^{E l c}\right)$, if any in the system, for each hour $(t)$ is calculated by subtracting the actual consumption of hydrogen-based M-CHP $\left(F_{H_{2}}^{M-C H P}(t)\right)$ from the average production $\left(F_{H_{2}}^{M-C H P-A v g}\right)$ and previous hour's storage content $(t-1)$.

$$
S_{H_{2}}^{E l c}(t)=S_{H_{2}}^{E l c}(t-1)+F_{H_{2}}^{M-C H P-A v g}-F_{H_{2}}^{M-C H P}(t)
$$

Production is decreased if during any hour the storage content $\left(S_{\mathrm{H}_{2}}^{E l c}\right)$ exceeds the capacity $\left(s_{\mathrm{H}_{2}}^{E l c}\right)$ as shown in Equation (8).

$$
\text { if } S_{\mathrm{H}_{2}}^{E l c}>s_{\mathrm{H}_{2}}^{E l c} \text { then } F_{\mathrm{H}_{2}}^{E l c}=F_{\mathrm{H}_{2}}^{E l c}-\left(S_{\mathrm{H}_{2}}^{E l c}-s_{\mathrm{H}_{2}}^{E l c}\right)
$$

However, production is increased if the storage content goes below zero.

$$
\text { if } S_{H_{2}}^{E l c}<0 \text { then } F_{H_{2}}^{E l c}=F_{H_{2}}^{E l c}-S_{H_{2}}^{E l c}
$$

At last, the electrolyser's minimum capacity is calculated by dividing the maximum production to fuel efficiency as shown in Equation (10).

$$
C_{\text {Min }}^{E l c}=\frac{\text { Hour } \max \left(F_{H_{2}}^{E l c}\right)}{\eta_{H_{2}}^{E l c}}
$$

The electricity generated by these electrolysers can be found using:

$$
P_{e}^{E l c}=\frac{F_{H_{2}}^{E l c}}{\eta_{H_{2}}^{E l l}}
$$

This model helps to decrease excess electricity production and power only production units in the system.

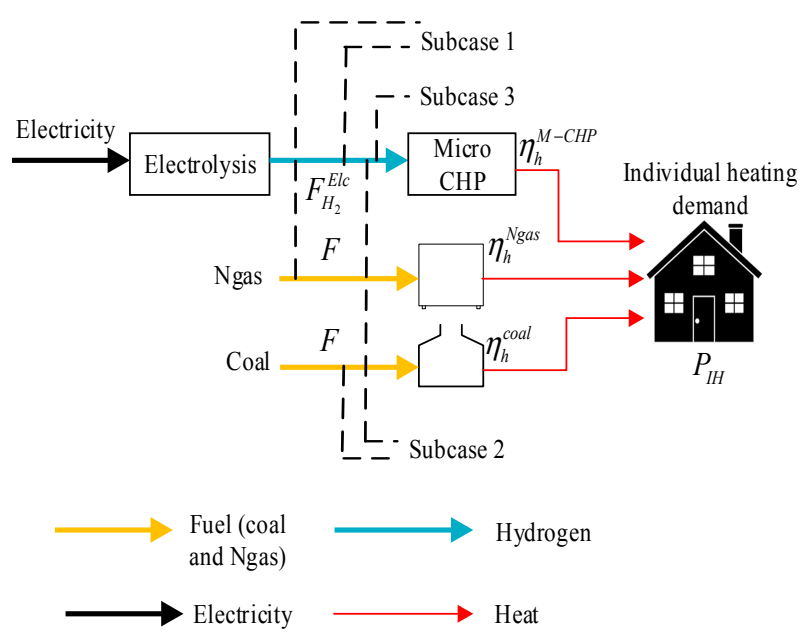

Figure 8. Coal, Ngas and $\mathrm{H} 2$ micro CHP are used to meet individual heating demand.

\subsection{Case 2: Ngas Micro CHP}

In case 2, M-CHP fired by Ngas is introduced and three subcases are considered to meet the individual heating demands as illustrated in Figure 9 and Equations (12)-(14). 


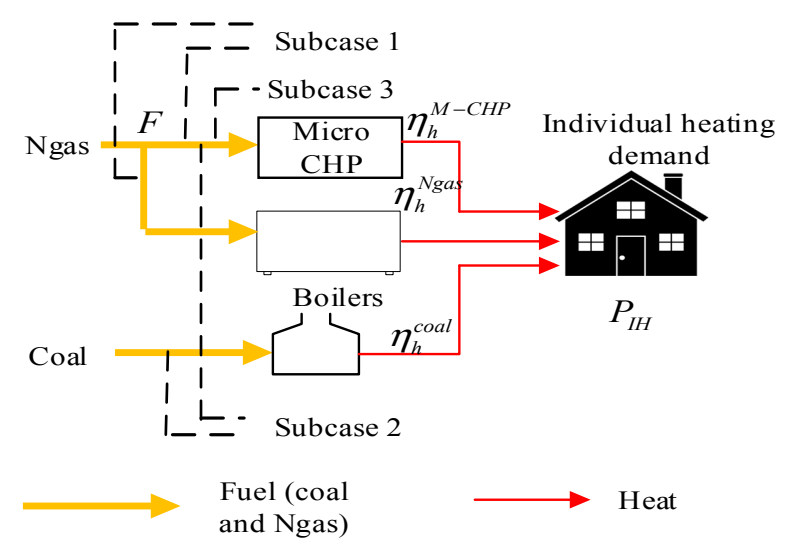

Figure 9. Coal, Ngas and Ngas micro CHP are used to meet individual heating demand.

For subcase 1, when IH demand is fulfilled by Ngas M-CHP and Ngas boilers, it can be represented as:

$$
P_{I H}=\left(F^{N g a s} \times \eta_{h}^{N g a s}\right)+\left(F^{N g a s} \times \eta_{h}^{M-C H P}\right)
$$

For subcase 2, when the $I H$ demand is met by Ngas $M-C H P$ and coal boilers, it can be represented as:

$$
P_{I H}=\left(F^{c o a l} \times \eta_{h}^{\text {coal }}\right)+\left(F^{\text {coal }} \times \eta_{h}^{M-C H P}\right)
$$

For subcase 3 , when $I H$ demand is met only by $M-C H P$, it can be represented as:

$$
P_{I H}=F^{N g a s} \times \eta_{h}^{M-C H P}
$$

\subsection{Case 3: Heat Pump}

The heat pumps use electricity from the grid to generate heating are the emission-free alternatives. Its performance is assessed by the electric efficiency that is generally expressed by the coefficient of performance (COP). A higher efficiency than coal and Ngas boilers make it a promising technology to lower carbon footprints [58]. However, the higher initial capital costs than boilers limit its use. Similar to the previous cases, the modelling of the three subcases is demonstrated by Figure 10 and Equations (15)-(17).

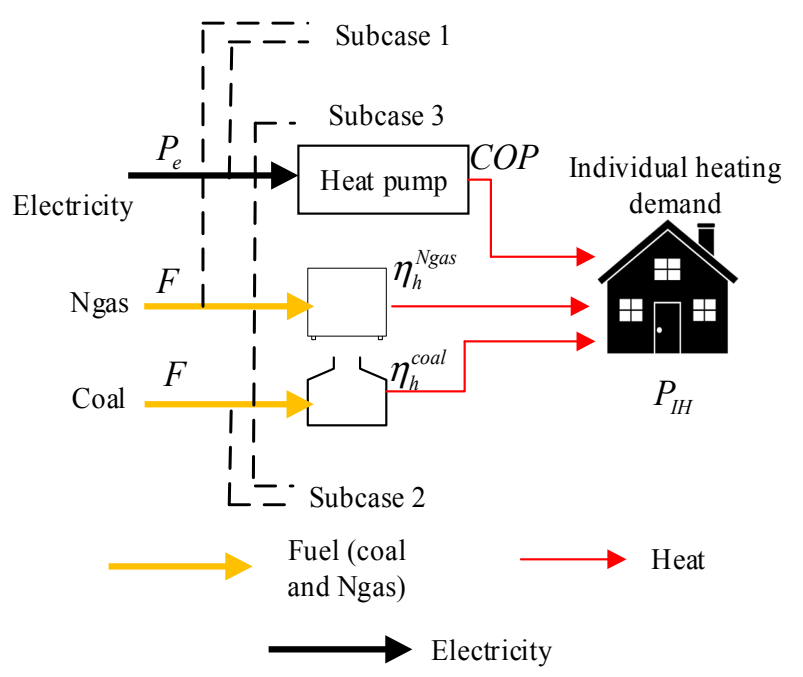

Figure 10. Coal, Ngas and heat pump are used to meet individual heating demand. 
Subcase 1:

$$
P_{I H}=\left(F^{N g a s} \times \eta_{h}^{N g a s}\right)+\left(P_{e} \times C O P\right)
$$

Subcase 2:

$$
P_{I H}=\left(F^{\text {coal }} \times \eta_{h}^{\text {coal }}\right)+\left(P_{e} \times C O P\right)
$$

Subcase 3:

$$
P_{I H}=P_{e} \times C O P
$$

\section{Modelling of Energy Storages}

\subsection{Pumped Hydro Storage}

The electricity storage in this work is modelled as pumped hydro storage (PHS) with the following components:

(i) Pump: It converts electricity into potential energy and is defined by capacity and efficiency.

(ii) Turbine: It converts potential energy to electricity and is defined by capacity and efficiency.

(iii) Storage: The total storing energy defined by capacity.

Charging and discharging of PHS is represented by Equation (18).

$$
S_{P H S}^{t+1}=S_{P H S}^{t}\left(1-\operatorname{LOSS}_{P H S}\right)+\left[P_{e, c h} \cdot \eta_{e, c h}-\frac{P_{e, d i s}}{\eta_{e, d i s}}\right] \Delta t
$$

where, subscripts $P H S, e, c h$, dis stand for pumped hydro storage, electricity charging and discharging respectively. $S_{P H S}^{t+1}$ shows total stored energy after charging and $S_{P H S}^{t}$ represents energy before charging. $L_{O S S_{P H S}}$ represents the energy loss during charging. $P_{e, c h}, \eta_{e, c h}$ represent the charging power and charging efficiency while $P_{e, d i s}, \eta_{e, d i s}$ demonstrates discharging power and discharging efficiency.

Charging and discharging capacities and efficiencies are shown in Table 3.

Table 3. Parameters for Pumped Hydro Storage.

\begin{tabular}{cccc}
\hline \multicolumn{2}{c}{ Charging } & \multicolumn{2}{c}{ Discharging } \\
\hline Capacity (MW) & Efficiency & Capacity (MW) & Efficiency \\
\hline 22,688 & 0.8 & 22,699 & 0.9 \\
\hline
\end{tabular}

Meanwhile, PHS with the above inputs can be used to model any type of storage, such as batteries. The simulation of PHS improves energy harnessing by renewable energy sources that avoid CEEP. In case when CEEP exceeds zero then the pump is used to fill the storage. However, the turbine is used to empty the storage by replacing the condensing unit's production.

\subsection{Rockbed Storage}

In the case of rockbed storage, electricity is stored in rock as heat during periods of low electricity prices and then used to produce electricity or heat during periods of high prices. Therefore, it creates a flexible energy supply and provides the opportunity for energy arbitrage $[59,60]$. This type of storage has a fast heat transfer rate, extended lifetime and higher thermal conductivity than other types of storages such as water [61]. Rockbed storage offers higher capacities and greater cycle lengths to match the volatility of renewable energy sources. Though it has a reduced efficiency due to storage loss during each hour (represented by LOSSRockbed), the fluctuation in electricity prices, low cost and easy scalability make this form of storage an economical alternative to use in HES infrastructure.

The rockbed is charged when RES generates surplus electricity during the day time or windy/sunny climate while it is discharged and generates steam for PP2 and CHP/PP1 when RES do not have sufficient supply as shown in Figure 11. 


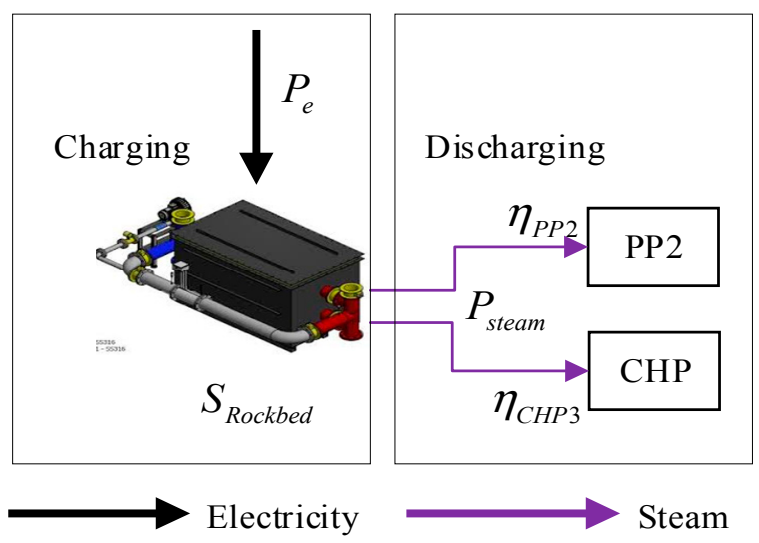

Figure 11. PHS charging and discharging phenomena.

The charging and discharging of rockbed is represented by Equation (19).

$$
S_{\text {Rockbed }}^{t+1}=S_{\text {Rockbed }}^{t}\left(1-\text { LOSS }_{\text {Rockbed }}\right)+\left[P_{e, c h} \cdot \eta_{e, c h}-\left(\frac{P_{\text {steam }, \text { dis }}}{\eta_{P P 2}}+\frac{P_{\text {steam }, \text { dis }}}{\eta_{C H P}}\right)\right] \Delta t
$$

where, subscript Rockbed represents rockbed storage. $S_{\text {Rockbed }}^{t+1}$ and $S_{\text {Rockbed }}^{t}$ correspond to the total stored energy after charging and before charging. $L O S S_{\text {Rockbed }}$ represents the energy loss during charging. $P_{e, c h}$ and $\eta_{e, c h}$ represent the charging power and charging efficiency while $P_{\text {steam, dis }}$ depicts the steam generated during discharging for condensing power units PP2 and CHP whose efficiencies are shown by $\eta_{P P 2}$ and $\eta_{C H P}$.

Rockbed storage components storage specifications including capacities, efficiencies, storage loss rate and share for $\mathrm{PP} / \mathrm{CHP}$ is shown in Table 4.

Table 4. Parameters for Rockbed Storage.

\begin{tabular}{ccccccc}
\hline \multicolumn{2}{c}{ Charging } & \multicolumn{2}{c}{ Discharging } \\
\hline $\begin{array}{c}\text { Capacity } \\
\text { (MW) }\end{array}$ & Efficiency & $\begin{array}{c}\text { Capacity } \\
\text { (MW) }\end{array}$ & Efficiency & $\begin{array}{c}\text { Storage } \\
\text { Loss Rate }\end{array}$ & $\begin{array}{c}\text { Share of } \\
\text { PP1/CHP }\end{array}$ & $\begin{array}{c}\text { Steam/Fuel } \\
\text { Ration }\end{array}$ \\
\hline 22,688 & 0.8 & 22,699 & 0.9 & 0.05 & 0.8 & 1 \\
\hline
\end{tabular}

\section{Results and Discussion}

Energy planning is a critical area in order to analyze a future energy system by determining sustainable and flexible alternatives. This section demonstrates the quantitative comparisons of cleaner heating solutions in individual heating infrastructure. Moreover, it also finds the technically viable storage to integrate maximum variable renewable energy. Therefore, multiple individual heating cases and different storages technical analysis are carried out to attain a sustainable, economically viable and decarbonized solution.

\subsection{Coal and Ngas Boilers in Individual Heating Infrastructure (Base Case)}

Thermal efficiency and fuel inputs of coal and Ngas boilers are required to meet individual heat demand and all these specifications are listed in Table 1.

Quantitative results of performance indicators such as total costs, $\mathrm{PES}$ and $\mathrm{CO}_{2}$ emissions calculated against the base case is calculated as $3246 \mathrm{GRMB}, 47,324 \mathrm{TWh} /$ year and 12,227 Mt respectively. The minimum condensing PP2 capacity requires the fulfillment of stabilizing units at 490,000 MWe. The maximum intermittent renewable electricity including wind and PV capacity is recorded as 407,616 and 38,899 MW. 


\subsection{Hydrogen Operated Micro CHP in Individual Heating Infrastructure (Case 1)}

Micro CHP fired by hydrogen is a carbon-free alternative to coal and Ngas and it is becoming popular in Europe especially in the UK and Germany to provide space and water heating $[62,63]$. Therefore, this work explores the role of M-CHP in devising a non-fossil and low carbon heat policy for China.

The electrolyser minimum capacity when replacing with coal boilers and Ngas boilers are found out to be 94,616 and 77,810 MWe respectively which were calculated from Equations (6)-(11). The inclusion of $\mathrm{H} 2 \mathrm{M}-\mathrm{CHP}$, apart from producing individual heating, generates electricity as well that is mentioned in the previous section. As more electricity is generated, PP2 also has to increase its capacity in order to maintain the $30 \%$ stabilizing unit ratio. Therefore, PP2 is increased up to 541,777 and 531,971 MWe in Subcases 1 and 2. However, hydrogen-based M-CHP addition allows to penetrate more renewable energy that increases wind share up to 456,078 and 454,612 MW in both subcases. Subcase 3 is also considered but is not included in the research as it is not a feasible option because the size of electrolyzer required will be quite large when M-CHP replaces both coal and Ngas boilers. It will enormously increase the annual costs. The impact of including M-CHP on total costs, PES and $\mathrm{CO}_{2}$-concentration for Subcases 1 and 2 are presented in Table 5.

Table 5. Case 1 (H2 Micro CHP) Components Specifications and Summary Performance.

\begin{tabular}{cccccccc}
\hline Subcase & Technology & $\begin{array}{c}\text { Electrolyser Minimum } \\
\text { Capacity (MWe) }\end{array}$ & $\begin{array}{c}\text { Fuel } \\
\text { Efficiency }\end{array}$ & $\begin{array}{c}\text { Storage } \\
\text { (GWh) }\end{array}$ & $\begin{array}{c}\text { Total Costs } \\
\text { (MRMB) }\end{array}$ & $\begin{array}{c}\text { PES } \\
\text { (TWh/Year) }\end{array}$ & CO $_{\mathbf{2}}$ (Mt) \\
\hline 1 & H2 Micro & 94,616 & 0.8 & \multirow{2}{*}{10} & $3,349,992$ & 47,230 & 12,149 \\
2 & CHP & 77,810 & & & $3,337,063$ & 47,406 & 12,228 \\
\hline
\end{tabular}

Coal boilers are the main source of emitting emissions and thereby replacing coal boilers with $\mathrm{H} 2$ M-CHP results in the least fuel consumption and case $(47,230.73 \mathrm{TWh} /$ year, $12,149.51 \mathrm{Mt})$ than base scenario (47,324.9 TWh/year, 12,227.47 Mt) and subcase 2 (47,406.26 TWh/year, 12,228.73 Mt). Micro $\mathrm{CHP}$, in this case, is operated by hydrogen which is produced by electrolysers. These phenomena of producing hydrogen by electrolysis are more expensive than Ngas and cheap coal reservoirs; therefore, the total costs increases in both subcases of case 1 in comparison to the base case.

\subsection{Natural Gas Operated Micro-CHP in Individual Heating Infrastructure (Case 2)}

As it has been observed in the above case that M-CHP is technically feasible for energy savings and reducing emission intensity. Further, if M-CHP fuel is replaced with Ngas, it becomes economically optimal because of the higher efficiency and low investment costs [18]. In this case, only the source of M-CHP from hydrogen is changed to Ngas as electrolysis phenomena are quite expensive so this case certainly helps more in reducing the total costs than case 1. Moreover, Table 6 depicts a comparison of all three subcases of case 2 in order to find out the most cost-effective and most decarbonized subcase.

Table 6. Case 2 (Ngas Micro CHP) Components Specifications and Summary Performance.

\begin{tabular}{cccccccc}
\hline Subcase & Technology & $\begin{array}{c}\text { Electric Efficiency } \\
\text { (MWe) }\end{array}$ & $\begin{array}{c}\text { Thermal } \\
\text { Efficiency }\end{array}$ & $\begin{array}{c}\text { Heat Demand } \\
\text { TWh/Year }\end{array}$ & $\begin{array}{c}\text { Total Costs } \\
\text { (MRMB) }\end{array}$ & $\begin{array}{c}\text { PES } \\
\text { (TWh/Year) }\end{array}$ & $\mathbf{C O}_{2}$ (Mt) \\
\hline 1 & Ngas micro & \multirow{2}{*}{0.3} & & 130.55 & $3,232,575$ & $47,099.96$ & $12,145.12$ \\
2 & CHP & & 0.65 & 107.36 & $3,237,530$ & $47,324.66$ & $12,239.75$ \\
3 & & & 237.91 & $3,207,927$ & $47,099.73$ & $12,082.69$ \\
\hline
\end{tabular}

The addition of Ngas M-CHP decreases all three performance indicators more than the base case and case 1 . The most economically feasible and less $\mathrm{CO}_{2}$ intensive emitter is Subcase 3 (when both coal and Ngas boilers are replaced with Ngas M-CHP) as it saves up to 57,056 million renminbi (MRMB) and decreases fuel consumption and $\mathrm{CO}_{2}$ emissions up to $225.17 \mathrm{TWh} /$ year and $144.78 \mathrm{Mt}$ of $\mathrm{CO}_{2}$ when compared with the base case. Further, Subcase 3 saves more than 129,136 MRMB in comparison 
to most economical subcase of case 1 (Ngas boilers are replaced with $\mathrm{H} 2 \mathrm{M}-\mathrm{CHP}$ ), and reduces fuel consumption and $\mathrm{CO}_{2}$ emissions up to $131 \mathrm{TWh} /$ year and $66 \mathrm{Mt}$ more than the most decarbonized subcase of case 1 (wherein coal boilers are replaced with H2 M-CHP).

\subsection{Heat Pumps in Individual Heating Infrastructure (Case 3)}

Besides using M-CHP for individual heating, electrification of heat by deploying heat pumps is also a good strategy to reduce reliance on fossil fuels and improve energy efficiency [64]. It uses less energy than conventional heating systems and many European countries have set ambitious targets to develop a low carbon society by exploiting heat pumps [65]. The comparison of all three subcases of case 3 is shown in Table 7. The inclusion of heat pumps in this work increases annual costs due to the high capital costs associated with them. Nevertheless, with a higher efficiency than boilers, using electricity to produce heating decreases fuel consumption and $\mathrm{CO}_{2}$ emissions not only in comparison to the base case, but also in comparison to all the subcases of cases 1 and 2.

Table 7. Case 3 (Heat Pump) Components Specifications and Summary Performance.

\begin{tabular}{ccccccc}
\hline Subcases & Technology & $\begin{array}{c}\text { Electric Efficiency } \\
\text { (MWe) }\end{array}$ & $\begin{array}{c}\text { Heat Demand } \\
\text { (TWh/year) }\end{array}$ & $\begin{array}{c}\text { Total Costs } \\
\text { (MRMB) }\end{array}$ & $\begin{array}{c}\text { PES } \\
\text { (TWh/Year) }\end{array}$ & CO $_{\mathbf{2}}$ (Mt) \\
\hline 1 & & & 130.55 & $3,317,509$ & $46,990.04$ & $12,096.86$ \\
2 & Heat pump & 3 & 107.36 & $3,307,377$ & $47,234.27$ & $12,200.07$ \\
3 & & & 237.91 & $3,231,864$ & $46,829.90$ & $12,075.00$ \\
\hline
\end{tabular}

Similar to case 2, subcase 3 proves out to be optimal as it reduces cost and emissions to minimum than Subcases 1 and 2.

A comparison of all the best cases (Subcase 2 of case 1, Subcase 3 of case 2 and Subcase 3 of case 3) is elaborated in the figure below (Figure 12). Only case 1 not economical because the annual costs are increased more than the base case total costs, which are shown as negative, while in the remaining best cases all the eminent factors decrease.

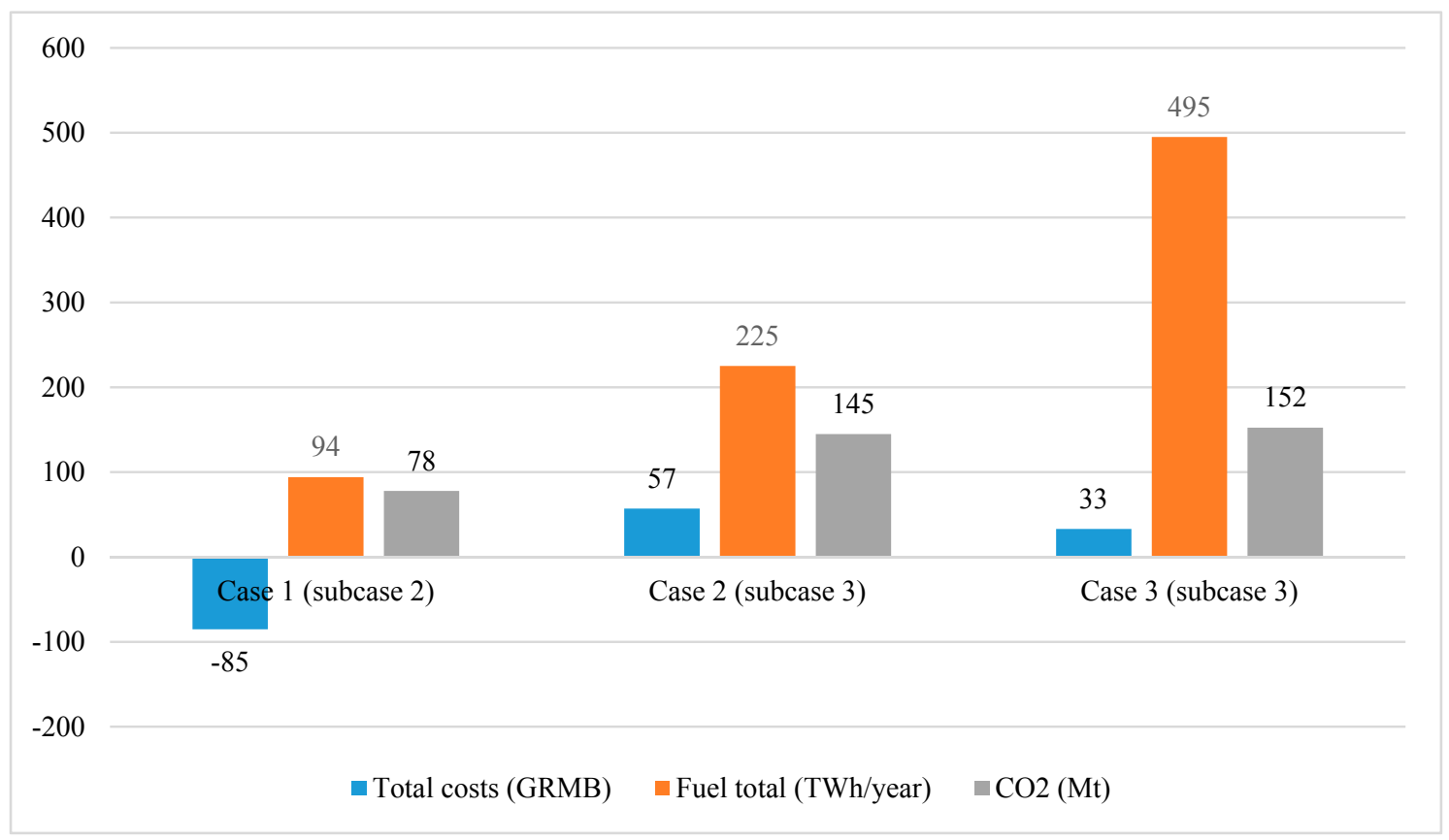

Figure 12. Comparisons of annual savings, fuel consumption and $\mathrm{CO}_{2}$ emissions of best subcases among all three cases.

The least-cost strategy is the inclusion of M-CHP (case 2) when replaced by both coal and Ngas boilers (Subcase 3) as it saves up to 57,056 MRMB. However, if the green atmosphere and reducing 
pollution is a priority, then the heat pump (case 3) replacement for both coal and Ngas boilers (subcase 3) is the best alternative solution, reducing fuel consumption up to $495 \mathrm{TWh} /$ year and $\mathrm{CO}_{2}$ emissions up to $152.47 \mathrm{Mt}$.

\subsection{Single Penstock Pumped Hydro Storage}

The most mature and well-established technology to match the fluctuations of renewable energy storage is PHS [13]. PHS usually has a single penstock that does not allow charging and discharging simultaneously. It charges during the night (when electricity prices are low) and discharges during high electricity demand in the day (when electricity prices are high). Although it facilitates renewable energy integration up to a certain limit, RES cannot provide grid stabilization.

Maximum RES generation in case of single PHS is $3157 \mathrm{TWh} /$ year while total costs, $\mathrm{PES}$ and $\mathrm{CO}_{2}$ emissions are $3265 \mathrm{GRMB}, 47,329 \mathrm{TWh} /$ year and 12,229 Mt, respectively. Although there is not much difference in quantitative results for two different simulation strategies as strategy 2 slightly decreases objective functions in comparison to strategy 1 . However, simulation strategy 1 in comparison to strategy 2 increases both CEEP and exportable excess electricity from $0 \mathrm{TWh} /$ year to 1.07 and 1.2 TWh/year, respectively. Further, the maximum wind and PV penetration is reached up to 407,616 and 388,999 MW, respectively.

\subsection{Double Penstock Pumped Hydro Storage}

The implementation of double penstock PHS not only decreases the investment costs but also provides greater flexibility to integrate renewable energy [66]. Therefore, renewable energy sources can replace conventional fossil fuel sources in order to offer grid stabilization if there is a possibility of charging and discharging PHS at the same time. Thus, PHS with the double penstock system provides this option, which not only facilitates RES integration, but also provides ancillary services that play an active role in grid stabilization. EnergyPLAN gives the option of PHS with double penstock by enabling the simultaneous operation of a turbine and pump in the energy storage tab. Therefore, by enabling this feature, it not only increases the flexibility by storing excess wind and balancing the electricity system, but also decreases all the prominent factors like annual costs, fuel consumption and $\mathrm{CO}_{2}$ emissions. During this double penstock PHS operation (when the simultaneous operation of turbine and storage is allowed), the maximum wind that can integrate into the system is increased up to 442,115 MW and the maximum condensing PP2 share is decreased to 457,142 MW. Maximum RES generation in comparison to single penstock increases from 3157 to $3457 \mathrm{TWh} /$ year and the quantitative results for other performance indicators (total costs, $\mathrm{PES}$ and $\mathrm{CO}_{2}$ emissions) are 2866 GRMB, 44,328 TWh/year and 10,732 Mt.

In comparison to PHS with single penstock, RES generation is increased, therefore, it results in decreasing PES and $\mathrm{CO}_{2}$ emissions from 47,324 to 44,324 TWh/year and 12,277 to 10,727.47 Mt. Further, it also proves to be cost-effective as it saves up to 400 billion RMB (GRMB).

\subsection{Rockbed Storage}

In this work, high-temperature thermal rock bed storage uses electricity to generate steam for condensing PP2 and CHP that results in reducing fuel demands. Further, low investment costs also decrease the total annual costs [19]. This storage is charged during excess electricity production and is therefore used to reduce critical excess and exportable excess electricity. Thus, this storage enables the accommodation of excess electricity in the form of steam and is fed to the condensing units (PP2 and CHP/PP1) which is represented by SHARERockbed in EnegyPLAN. It results in replacing the fuel consumption which is represented by $R A T I O_{\text {Fuel }}$ in Table 4.

By replacing the PHS storage with rockbed storage and assuming the same capacity of PHS storage, all the prominent factors are calculated as 3095 GRMB annual costs, 47,329 TWh/year PES and Mt of 12,228 emissions. 
As the capacity of rockbed storage is considered equal to PHS, so the maximum wind integration (407,616 MW) and RES generation (3157.61 TWh/year) remain the same. Likewise, the emission and total fuel consumption of PHS (single penstock) and rockbed storage are almost same, however, it decreases annual costs up to 3095 GRMB due to low investment cost.

To find out the most optimal storage: cost, emissions and fuel consumptions are evaluated for all three above mentioned cases. The comparisons between the above mentioned factors are illustrated in Figure 13.

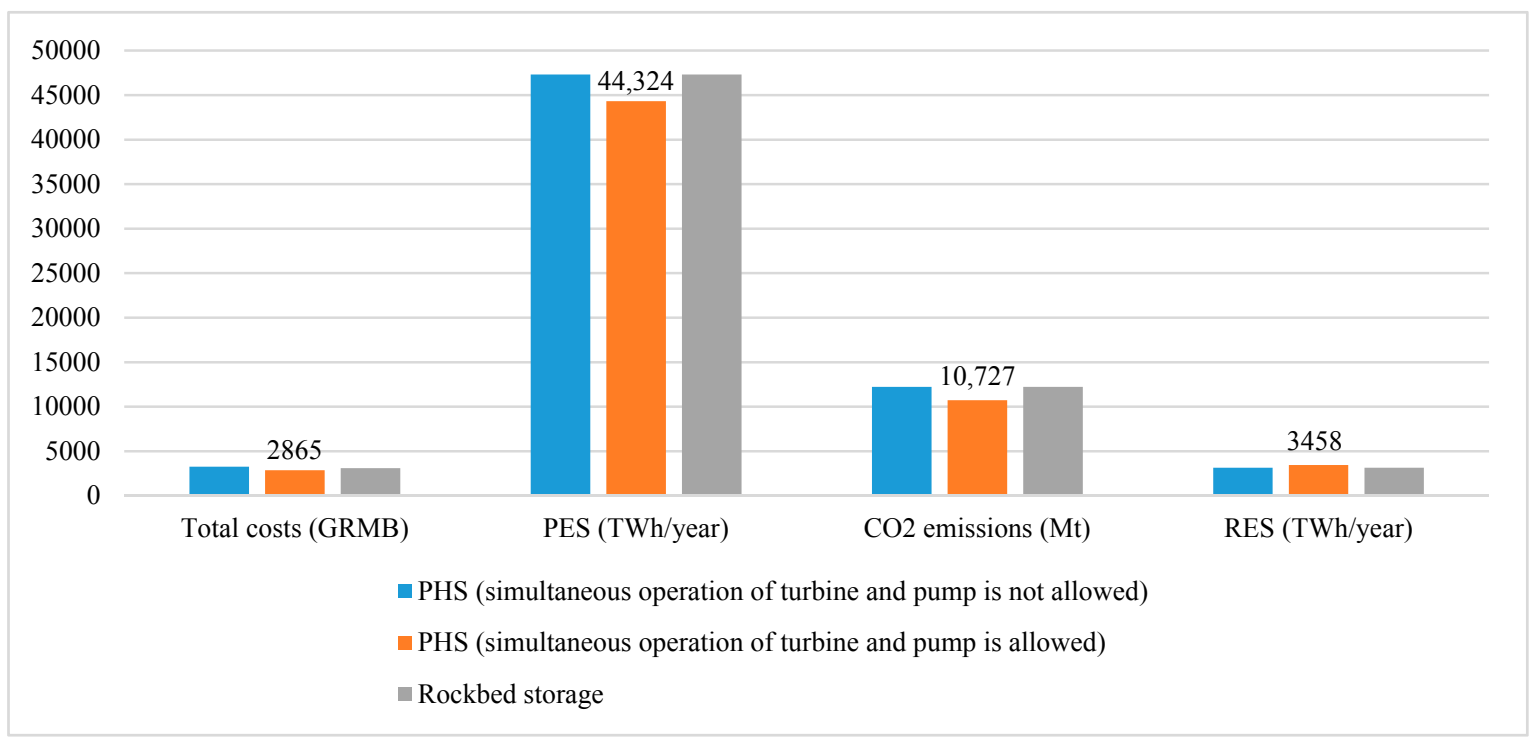

Figure 13. Comparisons of summary performance of single penstock PHS, double penstock PHS and rockbed storage.

As can be seen in Figure 13, PHS during the simultaneous operation of the turbine and pump reduces all the objective functions more than rockbed storage and PHS with a single penstock. However, PHS with double penstock integrates maximum amount of wind integration and also reduces PP2 share that's why it results in least emission and cost. Nevertheless, considering the same storage capacity that integrates the same amount of RES, rockbed is considered more cost-effective than PHS (single penstock and double penstock) due to its cheaper initial investment cost than PHS.

\section{Conclusions}

This study applied the EnergyPLAN tool for the HES modelling of China for year 2030. Multiple storage options and different individual heating alternatives are investigated in order to integrate the maximum IRE share and to attain cleaner heating solutions. Two different simulation strategies are employed for the technical analysis of single penstock PHS, double penstock PHS and rockbed storages. The simultaneous activation of turbine and pump adds 34,499 MW more IRE share to the system while decreasing $3000 \mathrm{TWh} /$ year fuel consumption and $1500 \mathrm{Mt}$ emissions in comparison to rockbed and single penstock PHS. Rockbed storage decreases annual costs up to 3095 GRMB due to the low investment costs required whereas double penstock reduces annual costs up to 2865 GRMB because its simultaneous activation feature helps in integrating the maximum IRE as well as reducing condensing units share.

In addition, coal and Ngas boilers in heating infrastructure are used to meet individual heating demand which is considered as a base case for this work. To investigate the economic performance and low carbon alternatives, hydrogen-based M-CHP (case 1), Ngas M-CHP (case 2) and heat pumps (case 3) are included. Each of these three cases are further divided into three subcases that have been elaborated in Section 4. Ngas M-CHP when replaced by both the coal and Ngas boilers (subcase 3 of case 2) of the base case is more cost-effective than the rest of the cases as it saves up to 57,056 MRMB. 
Nonetheless, the most decarbonized alternative method involves the addition of a heat pump because it decreases fuel consumption and emission up to $495 \mathrm{TWh} /$ year and $152 \mathrm{Mt}$ of $\mathrm{CO}_{2}$ due to its higher efficiency than the boiler and M-CHP. These additions achieve substantial benefits in the electricity and heat network that not only improve energy security but also make the hybrid energy system fuel efficient and economically optimal.

Author Contributions: M.F.T. and M.S.J. did the simulation work and wrote the manuscript. H.C. supervise the project and propose the smart energy hub. I.J., A.K. and S.A. checked the model and proofread the manuscript.

Funding: This work was supported by the National key Research and Development Program of China (2016YFB0900100).

Acknowledgments: The authors would like to thank the editor and reviewers for their valuable suggestions and useful comments that helps in improving the quality of this paper.

Conflicts of Interest: The authors declare no conflict of interests.

\section{Nomenclature}

\section{Indices}

$t \quad$ Time period of one whole year $=8784 \mathrm{~h}$

$x \quad$ Type of energy $x=e$ (electricity) orh(heat)

$e \quad$ Represents electricity

$h \quad$ Represent heat

$\mathrm{H}_{2} \quad$ Hydrogen produced by electrolysers

F Fuel input, total amount of fuel

$\eta \quad$ Efficiency

Constants

$F^{\text {coal }}, F^{N g a s}$

$F_{H_{2}}^{E l c}$

${ }_{\mathrm{H}_{\mathrm{H}}}^{\mathrm{M}-\mathrm{CHP}-\mathrm{Avg}}$

${ }^{\mathrm{F}_{2}}{ }^{\mathrm{B}}$

$\eta_{h}^{B}$

$\eta_{h \text { coal }}^{\text {coas }}$

$\eta_{h}^{N g a s}$
$\eta_{h}^{M-C H P}$

$\eta_{h, c h}, \eta_{e, d i s}$

$\eta_{P P 2}, \eta_{C H P}$

$\eta_{h}^{B}$

$\eta_{x, c h}, \eta_{x, d i s}$

COP

Variables

$S_{P H S}^{t}, S_{\text {Rockbed }}^{t}$

$S_{P H S}^{t+1}, S_{\text {Rockbed }}^{t+1}$

LOSS $_{\text {PHS }}$, LOSS $_{\text {Rockbed }}$

$\mathrm{S}_{\mathrm{H}_{2}}^{\mathrm{Elc}}$

$s_{\mathrm{H}_{2}}^{\mathrm{Elc}}$

$C_{\text {Min }}^{\text {Elc }}$

$P_{e}$

$P_{I H}$

$P_{e, c h}, P_{e, d i s}$

$P_{\text {steam, dis }}$
Coal and Ngas boiler input

Hydrogen fuel input for M-CHP produced by electrolysers

Hydrogen consumption of M-CHP

Boiler efficiency

Coal boiler efficiency

Natural gas boiler efficiency

Micro CHP efficiency

Charging and discharging efficiency

Condensing units (thermal power plants and CHP efficiency)

Boiler efficiency

Charging and discharging efficiency

Coefficient of performance of heat pump

Total stored energy before charging

Total stored energy after charging

Energy loss during charging PHS

Hyrdogen storage content

Hydrogen storage capacity

Minimum electrolyzer capacity

Total electricity generated by smart energy hub

Total individual heating demand

Charging and discharging power of PHS

Steam generated during discharging of rockbed storage

\section{References}

1. Outlook, A.E. Annual Energy Outlook 2014; US Energy Information Administration: Washington, DC, USA, $2014 ;$ p. 2. 
2. Ezzati, S.M.; Faghihi, F.; Shourkaei, H.M.; Mozafari, S.B.; Soleymani, S. Optimum operation of multi-energy carriers in the context of an energy hub considering a wind generator based on linear programming. J. Renew. Sustain. Energy 2018, 10, 014702. [CrossRef]

3. Beigvand, S.D.; Abdi, H.; La Scala, M. Economic dispatch of multiple energy carriers. Energy 2017, 138, 861-872. [CrossRef]

4. Hanmer, C.; Shipworth, M.; Shipworth, D.; Carter, E. How household thermal routines shape UK home heating demand patterns. Energy Effic. 2019, 12, 5-17. [CrossRef]

5. Berger, M.; Worlitschek, J. A novel approach for estimating residential space heating demand. Energy 2018, 159, 294-301. [CrossRef]

6. Werner, S. International review of district heating and cooling. Energy 2017, 137, 617-631. [CrossRef]

7. Zhang, J.; Di Lucia, L. A transition perspective on alternatives to coal in Chinese district heating. Int. J. Sustain. Energy Plan. Manag. 2015, 6, 49-69.

8. Wang, J.; Zhong, H.; Ma, Z.; Xia, Q.; Kang, C. Review and prospect of integrated demand response in the multi-energy system. Appl. Energy 2017, 202, 772-782. [CrossRef]

9. Zheng, X.; Wei, C.; Qin, P.; Guo, J.; Yu, Y.; Song, F.; Chen, Z. Characteristics of residential energy consumption in China: Findings from a household survey. Energy Policy 2014, 75, 126-135. [CrossRef]

10. Werner, S.; Gong, M. District Heating Research in China; Report 2014. Available online: http://www.divaportal.org/smash/record.jsf?pid=diva2:774851 (accessed on 31 May 2019).

11. Krause, T.; Andersson, G.; Frohlich, K.; Vaccaro, A. Multiple-energy carriers: Modeling of production, delivery, and consumption. Proc. IEEE 2011, 99, 15-27. [CrossRef]

12. Mohammadi, M.; Noorollahi, Y.; Mohammadi-Ivatloo, B.; Yousefi, H. Energy hub: From a model to a concept-A review. Renew. Sustain. Energy Rev. 2017, 80, 1512-1527. [CrossRef]

13. Yang, C.-J. Chapter 2-Pumped Hydroelectric Storage. In Storing Energy; Letcher, T.M., Ed.; Elsevier: Oxford, UK, 2016; pp. 25-38.

14. Heller, L.; Gauché, P. Modeling of the rock bed thermal energy storage system of a combined cycle solar thermal power plant in South Africa. Sol. Energy 2013, 93, 345-356. [CrossRef]

15. Rehman, S.; Al-Hadhrami, L.M.; Alam, M.M. Pumped hydro energy storage system: A technological review. Renew. Sustain. Energy Rev. 2015, 44, 586-598. [CrossRef]

16. Steffen, B. Prospects for pumped-hydro storage in Germany. Energy Policy 2012, 45, 420-429. [CrossRef]

17. Ma, T.; Yang, H.; Lu, L. Feasibility study and economic analysis of pumped hydro storage and battery storage for a renewable energy powered island. Energy Convers. Manag. 2014, 79, 387-397. [CrossRef]

18. Hänchen, M.; Brückner, S.; Steinfeld, A. High-temperature thermal storage using a packed bed of rocks-Heat transfer analysis and experimental validation. Appl. Therm. Eng. 2011, 31, 1798-1806. [CrossRef]

19. Sarbu, I.; Sebarchievici, C. A comprehensive review of thermal energy storage. Sustainability 2018, 10, 191. [CrossRef]

20. Yoon, T.; Ma, Y.; Rhodes, C. Individual Heating systems vs. District Heating systems: What will consumers pay for convenience? Energy Policy 2015, 86, 73-81. [CrossRef]

21. Connolly, D.; Lund, H.; Mathiesen, B.V.; Werner, S.; Möller, B.; Persson, U.; Boermans, T.; Trier, D.; Østergaard, P.A.; Nielsen, S. Heat Roadmap Europe: Combining district heating with heat savings to decarbonise the EU energy system. Energy Policy 2014, 65, 475-489. [CrossRef]

22. Allison, J.; Murphy, G.B.; Counsell, J.M. Control of micro-CHP and thermal energy storage for minimising electrical grid utilisation. Int. J. Low-Carbon Technol. 2014, 11, 109-118. [CrossRef]

23. Pascuzzi, S.; Anifantis, A.; Blanco, I.; Scarascia Mugnozza, G. Electrolyzer performance analysis of an integrated hydrogen power system for greenhouse heating. A case study. Sustainability 2016, 8, 629. [CrossRef]

24. Lund, H. EnergyPLAN, Advanced Energy Systems Analysis Computer Model; Documentation Version 14; Sustainable Energy Planning Research Group: Aalborg, Denmark, 2017.

25. Connolly, D.; Lund, H.; Mathiesen, B.V.; Leahy, M. The first step towards a $100 \%$ renewable energy-system for Ireland. Appl. Energy 2011, 88, 502-507. [CrossRef]

26. Lund, H.; Østergaard, P.A.; Stadler, I. Towards 100\% renewable energy systems. Appl. Energy 2011, 88, 419-421. [CrossRef] 
27. Krajačić, G.; Duić, N.; Zmijarević, Z.; Mathiesen, B.V.; Vučinić, A.A.; da Graça Carvalho, M. Planning for a $100 \%$ independent energy system based on smart energy storage for integration of renewables and $\mathrm{CO}_{2}$ emissions reduction. Appl. Therm. Eng. 2011, 31, 2073-2083. [CrossRef]

28. Porubova, J.; Bazbauers, G. Analysis of long-term plan for energy supply system for Latvia that is $100 \%$ based on the use of local energy resources. Sci. J. Riga Tech. Univ. Environ. Clim. Technol. 2010, 4, 82-90. [CrossRef]

29. Groenewoud, R. Energy Self-Sufficient Neighborhoods in the Netherlands: A Technical Framework on the Energy Storage \& Land Usage Requirement for Intermittent Renewable Energy Systems. Master's Thesis, Utrecht University, Heidelberglaan, The Netherlands, 2013.

30. Krajačić, G.; Duić, N.; da Graça Carvalho, M. How to achieve a 100\% RES electricity supply for Portugal? Appl. Energy 2011, 88, 508-517. [CrossRef]

31. Ćosić, B.; Krajačić, G.; Duić, N. A 100\% renewable energy system in the year 2050: The case of Macedonia. Energy 2012, 48, 80-87. [CrossRef]

32. Child, M.; Breyer, C. Vision and initial feasibility analysis of a recarbonised Finnish energy system for 2050. Renew. Sustain. Energy Rev. 2016, 66, 517-536. [CrossRef]

33. Ma, T.; Østergaard, P.A.; Lund, H.; Yang, H.; Lu, L. An energy system model for Hong Kong in 2020. Energy 2014, 68, 301-310. [CrossRef]

34. Liu, L.; Zhu, T.; Pan, Y.; Wang, H. Multiple energy complementation based on distributed energy systems-Case study of Chongming county, China. Appl. Energy 2017, 192, 329-336. [CrossRef]

35. Zhao, G.; Guerrero, J.M.; Jiang, K.; Chen, S. Energy modelling towards low carbon development of Beijing in 2030. Energy 2017, 121, 107-113. [CrossRef]

36. Hong, L.; Lund, H.; Möller, B. The importance of flexible power plant operation for Jiangsu's wind integration. Energy 2012, 41, 499-507. [CrossRef]

37. Bazbauers, G.; Cimdina, G. The role of the Latvian district heating system in the development of sustainable energy supply. Sci. J. Riga Tech. Univ. Environ. Clim. Technol. 2011, 7, 27-31. [CrossRef]

38. Thellufsen, J.Z.; Nielsen, S.; Lund, H. Implementing cleaner heating solutions towards a future low-carbon scenario in Ireland. J. Clean. Prod. 2019, 214, 377-388. [CrossRef]

39. Lund, H.; Duic, N.; Østergaard, P.A.; Mathiesen, B.V. Future district heating systems and technologies: On the role of smart energy systems and 4th generation district heating. Energy 2018, 165, 614-619. [CrossRef]

40. Lund, H.; Werner, S.; Wiltshire, R.; Svendsen, S.; Thorsen, J.E.; Hvelplund, F.; Mathiesen, B.V. 4th Generation District Heating (4GDH): Integrating smart thermal grids into future sustainable energy systems. Energy 2014, 68, 1-11. [CrossRef]

41. Lund, H.; Münster, E. Modelling of energy systems with a high percentage of CHP and wind power. Renew. Energy 2003, 28, 2179-2193. [CrossRef]

42. Lund, H.; Clark, W.W. Management of fluctuations in wind power and CHP comparing two possible Danish strategies. Energy 2002, 27, 471-483. [CrossRef]

43. Chen, M.; Lund, H.; Rosendahl, L.A.; Condra, T.J. Energy efficiency analysis and impact evaluation of the application of thermoelectric power cycle to today's CHP systems. Appl. Energy 2010, 87, 1231-1238. [CrossRef]

44. Meiere, I.; Bazbauers, G. Sustainability Analysis of Innovative Transport System. Sci. J. Riga Tech. Univ. Environ. Clim. Technol. 2011, 6, 63-68. [CrossRef]

45. Lund, H.; Kempton, W. Integration of renewable energy into the transport and electricity sectors through V2G. Energy Policy 2008, 36, 3578-3587. [CrossRef]

46. Udrene, L.; Bazbauers, G. Role of vehicle-to-grid systems for electric load shifting and integration of intermittent sources in Latvian power system. Energy Procedia 2015, 72, 156-162. [CrossRef]

47. Šare, A.; Krajačić, G.; Pukšec, T.; Duić, N. The integration of renewable energy sources and electric vehicles into the power system of the Dubrovnik region. Energy Sustain. Soc. 2015, 5, 27. [CrossRef]

48. Tahir, M.F.; Haoyong, C.; Mehmood, K.; Ali, N.; Bhutto, J.A. Integrated Energy System Modelling of China for 2020 by Incorporating Demand Response, Heat Pump and Thermal Storage. IEEE Access 2019, 7, 40095-40108. [CrossRef]

49. Tahir, M.F.; Tehzeeb ul, H.; Saqib, M.A. Optimal scheduling of electrical power in energy-deficient scenarios using artificial neural network and Bootstrap aggregating. Int. J. Electr. Power Energy Syst. 2016, 83, 49-57. [CrossRef] 
50. FaizanTahir, M. Optimal Load Shedding Using an Ensemble of Artificial Neural Networks. Int. J. Electr. Comput. Eng. Syst. 2016, 7, 39-46.

51. Statistics, B.E.O. BP Energy Outlook 2016 Edition: Outlook to 2035; British Petroleum Statistics: London, UK, 2016.

52. Suganthi, L.; Samuel, A.A. Energy models for demand forecasting-A review. Renew. Sustain. Energy Rev. 2012, 16, 1223-1240. [CrossRef]

53. Energy, I.; Change, C. World Energy Outlook Special Report (2015); IEA: Paris, France, 2017; p. 37.

54. China Three Gorges Corporation. Water Regimen Information; China Three Gorges Corporation: Yichang, China, 2017.

55. State Grid Corporation Power Supply and Sale Statistic; State Grid Corporation: Beijing, China, 2017.

56. China Electricity Council. Annual Report of China's Power Sector Development Beijing; China Electricity Press: Beijing, China, 2017.

57. China Electricity Council. China Power Industry Statistic in 2017; China Electricity Council: Beijing, China, 2017.

58. Staffell, I.; Brett, D.; Brandon, N.; Hawkes, A. A review of domestic heat pumps. Energy Environ. Sci. 2012, 5, 9291-9306. [CrossRef]

59. Allen, K.; von Backström, T.; Joubert, E.; Gauché, P. Rock bed thermal storage: Concepts and costs. AIP Conf. Proc. 2016, 1734. [CrossRef]

60. Basso, G.L.; Paiolo, R. A preliminary energy analysis of a commercial CHP fueled with H2NG blends chemically supercharged by renewable hydrogen and oxygen. Energy Procedia 2016, 101, 1272-1279. [CrossRef]

61. Chua, K.J.; Chou, S.K.; Yang, W. Advances in heat pump systems: A review. Appl. Energy 2010, 87, 3611-3624. [CrossRef]

62. De Wit, J.; Mofid, I.; Frederiksen, K.V. Implementation of micro CHP in single-family houses. In Proceedings of the 23rd World Gas Conference, Amsterdam, The Netherlands, 5-9 June 2006; International Gas Union: Amsterdam, The Netherlands, 2006.

63. Dodds, P.E.; Staffell, I.; Hawkes, A.D.; Li, F.; Grünewald, P.; McDowall, W.; Ekins, P. Hydrogen and fuel cell technologies for heating: A review. Int. J. Hydrog. Energy 2015, 40, 2065-2083. [CrossRef]

64. Laubscher, H.F.; von Backström, T.W.; Dinter, F. Developing a cost effective rock bed thermal energy storage system: Design and modelling. AIP Conf. Proc. 2017, 1850. [CrossRef]

65. Wang, Z. Heat pumps with district heating for the UK's domestic heating: Individual versus district level. Energy Procedia 2018, 149, 354-362. [CrossRef]

66. Anagnostopoulos, J.; Papantonis, D. Study of hybrid wind-hydro power plants operation and performance in the autonomous electricity system of Crete Island. In Recent Advances in Energy, Environment and Economic Development, Proceedings of the 3rd International Conference on Development, Energy, Environment, Economics; WSEAS Press: Paris, France, 2012; pp. 239-246.

(C) 2019 by the authors. Licensee MDPI, Basel, Switzerland. This article is an open access article distributed under the terms and conditions of the Creative Commons Attribution (CC BY) license (http://creativecommons.org/licenses/by/4.0/). 